\title{
ARE EXISTING ADMINISTRATIVE PARADIGMS CAPABLE OF PRODUCING THE TOOLS TO RESOLVE THE CONTEMPORARY ADMINISTRATIVE CRISIS?
}

\section{Barabashev Alexey G.}

Doctor of Philosophy, Professor of the National

Research University Higher School of Economics.

Address: Myasnitskaya 20, Moscow, 101000, Russian Federation.

E-mail: abarabashev@hse.ru

\begin{abstract}
The hypothesis of the article is that the basic administrative paradigms (Weberian and neo-Weberian; NPM; New Public Governance) are not capable of providing tools and procedures (sets of administrative mechanisms, attributed to the basic administrative paradigms) for governance which are suitable for overcoming the global administrative crisis. The arguments in support of this hypothesis are outlined through an analysis of scenarios of using such administrative mechanisms under the conditions of administrative crisis: (a) to use each set of administrative mechanism (or to limit their usage through some "good mechanisms") in the practice of governance despite their attribution to different basic administrative paradigms; (b) to select the "best" basic administrative paradigm and to only follow this particular vision with recommendations on how to shape the administration and its work.

In the final part of the article the possible principles of a new administrative paradigm that could be relevant to the fast-changing contemporary situation and current instability are discussed.
\end{abstract}

Keywords: administrative crisis; public administration reform; administrative paradigm; administrative mechanisms; effective state.

Citation: Barabashev, A.G. (2016). Are existing administrative paradigms capable of providing tools to resolve the contemporary administrative crisis? Public Administration Issues, no 5 (Special Issue, electronic edition), pp. 6-25 (in English).

\section{General Introduction into the Subject}

(administrative crisis and administrative paradigms)

As this article is the second in a series of research papers dedicated to the author's discovery of a new Effective State paradigm (see the first article: Baraba- 
shev, 2016 - in Russian), I would like to start with a brief introductory description, mainly for English speaking readers, of the approach and ideas described in the first article that are used as the foundation for the present research.

Recently, we have witnessed, worldwide, the escalating appearance of different local conceptual complexes of innovations which combine scientific, technological, economic, and social entities. Such complexes are increasingly influencing countries' development. States all over the contemporary world need the creation of new approaches to management in the new, rapidly changing conditions of innovative turmoil. This means that instead of the globalization of governance based on multinational agreements and on the coordination of hierarchical stability, a new governance reality affects every country, without exclusion, in terms of conditions of instability and uncertainty. The last decade has clearly shown that administrative tools and procedures of governance (socalled administrative mechanisms) should be heavily and repeatedly re-shaped and modernized.

The administrative crisis that is a consequence of imbalances produced by innovative development highlights the incapability of national governments to react properly to new kinds of challenges. Mistrust in governments, a lack of many globalist initiatives, economic volatility, the appearance of numerous international conflicts, and the attempts of many countries "to find their own way" are all based on governments losing their grip through their resistance to address administrative crisis.

On the level of public administration theory, as described in the first article, all three basic administrative paradigms, namely, Weberian and neo-Weberian (the latter is consistent with the Weberian approach, because both are interpreting state and bureaucracy as a subject), the New Public Management paradigm (with its interpretation of state and bureaucracy as a set of administrative service functions), and the New Public Governance paradigm (which describes the state and civil service as a network of relations with civil society), produce chains of theories and models that purport to elaborate the administrative mechanisms capable of overcoming the recent administrative crisis in the best way. Again, such theories and models respond differently to the modern administrative crisis, which consists of a sequence of rapid and uneven innovative challenges that are impossible to reject and quite difficult to accept.

In order to briefly describe the essence of the basic administrative paradigm approaches to solving the contemporary administrative crisis, it is important to note that these approaches are rather different. The Weberian paradigm proposes administrative mechanisms to reconstruct the system of government bodies based on the explication and division of their responsibilities, and to increase the professional competences of public servants according to their specifics. The Neo-Weberian approach stresses the idea that the ethical essence of professional behavior and the motivation to serve people should be placed at the center of efforts to make governance better. NPM reacts to the crisis with two sorts of proposals: first, from an external perspective, how to specify the functions of government bodies, paying attention mainly to the regulation of service functions (i.e., improvement of services delivery), and to control the strength- 
ening of functions, including relations with civil society, and how to outsource functions from the public sector to the private sector. Secondly, from an internal point of view, for public service, NPM proposed mechanisms on how to downsize staff on the basis of its KPI, to reduce the transaction costs of state management. Finally, Good Governance, or New Public Governance, as it is sometimes called, is a paradigm which made advances in increasing the openness and transparency of governments, and on the co-productive relations between the government and its citizens (Bingham, Nabatchi \& O'Leary, 2005; Hințea, Profiroiu \& Tțiclău, 2015).

\section{The introduction to the research questions}

(The divergence of the best governance practices

are far beyond the existing basic administrative paradigms)

The potential of the existing administrative paradigm is evident in its reaction to the current administrative crisis. Recently, as an expert group member of the Russian Labor and Social Protection Ministry (ML), I had the chance to see the public authorities' work. Due to the need for the elaboration of administrative mechanisms that are suitable for the rapidly changing conditions of governance in our country, in circumstances of full scale economic (and not only economic) turbulence, the ML, which is responsible for civil service management, announced a national competition among the government and municipal bodies. The call for an annual competition, now entering its third year (ML of Russia, competitions, 2016), solicits best practices in governance from state entities in the areas of human resource management, including the search for and selection of personnel, qualification requirements, professional adaptation, professional development, motivation and remuneration, professional culture, anti-corruption techniques, rotation and transfer to other positions, attestation and qualified exams, personnel reserves, information technology for HR management, and other topics formulated by the applicants (entities) themselves. Two cycles of the competition were resulted through the decisions of the expert group regarding which practices are best, and whether they can be replicated by other bodies.

At the time of the evaluations it was impossible to recognize any anomalies in the results, especially at the second competition cycle (2015) when over 200 applications from governmental bodies were received. Over time, however, I have recognized that almost all of the selected best practices have some remarkable features. In the 2015 competition we found several unusual aspects (the best practices are presented in their entirety at the: ML of Russia, best practices, 2016):

(1) All of the best practices are connected with dramatic cuts in financing;

(2) Most applications were dedicated to non-standard procedures involving how to find (select) the appropriate personnel capable of finding flexible solutions to problems. Such practices were much appreciated. They are not intended to improve the legislation, but rather to find mechanisms for the implementation of norms; 
(3) Second in number were those best practices showing how to develop the abilities of personnel in order to adapt to rapidly changing conditions of governance, including the ability to undertake continuous education and self-development;

(4) Third in number were best practices on how to evaluate the outcomes (not outputs) of civil servant activity beyond the existing KPIs;

(5) At the core of almost all the best practices was a strategy of working with personnel, along with the evaluation of the quality of personnel based on the results of the strategy implementation;

(6) To sum up, the administrative mechanisms proposed by government bodies were heterogeneous and in some significant points went far beyond the tools and procedures proposed by the basic administrative paradigms. Great dissatisfaction with governmental and municipal bodies about "standard" mechanisms is clearly evident.

Remarkably, almost the same situation regarding the variety of practices beyond the NPM framework is mentioned in the workings of other EU countries' governments (De Vries, Nemec, 2013). Heterogeneity of contexts and tools for strategic planning strongly requires flexibility and a willingness to learn throughout the process (Bryson, 2004) is seen at the local departmental level in the USA (Edvards, 2012). We can conclude that the present practices of governance should be understood from the position of existing basic administrative paradigms: if these paradigms are capable of providing practices of governance with "one-size-fits-all" tools or not.

\section{The research questions (about which administrative mechanisms are better for governance in the current administrative crisis)}

Due to the difference in the basic paradigms' "recipes for practitioners" it is necessary to answer the questions: "Which administrative mechanisms are better to select for the elimination of the governance shortcomings at the time of an administrative crisis, and why?". Some questions on the usage of the administrative mechanism should be asked, starting with the simplest and then proceeding to the more complicated and theoretically stronger:

Question 1. Is it possible to follow the easiest managerial decision for the contemporary practice of governance: to accept all the administrative mechanisms from different administrative paradigms simultaneously, without paying attention to the theoretical heterogeneity of the proposed instruments? Actually, governments are mostly used to this way of acting (Pollitt, Bouckaert, 2011). However, the problem of accepting the results of such a "theoretically omnivorous" approach is vital: an eclectic application of the mechanisms from different theories in practice, despite their controversial background and disagreements, could entail negative consequences. My hypothesis is that this can't be a proper decision, because theoretical unscrupulousness makes the practice of governance weaker, especially under conditions of crisis, when the cost of administrative mistakes is much higher. 
Question 2. A more advanced question: is it possible to select the best mechanisms elaborated in different paradigms and to only use the good procedures and tools despite the differences in their theoretical roots? For NPM and Good Governance, as an example, M. De Vries and J. Nemec outlined, that "Nonetheless, many NMP based tools and instruments are still being used and optimized in order to support the process of improvement. Internally, governments are still trying to optimize their internal work. Externally, a shift from emphasizing minimal government (NPM) into trends toward good governance is indeed visible" (De Vries, Nemec, 2013, P. 13). To generalize and re-formulate the question of selective usage: what are the comparative shortcomings of the theories and approaches developed within the framework of the main administrative paradigms of public administration? Which administrative mechanisms should be neglected, and which are better kept in the managerial arsenal? To answer these questions it is necessary to take into account both the theoretical arguments (requirements for completeness, and the theoretical justification of administrative mechanisms), and the disadvantages associated with the practical solutions proposed by such administrative mechanisms. The hypothesis of selecting and simultaneously using essentially the best administrative mechanisms from different paradigms is impossible here because of the strict contradictions in the organizational implementation of such heterogeneous mechanisms.

Question 3. The last and "strongest question" is about the possibility of selecting only those mechanisms that belong to an exclusively administrative paradigm. For example, the neo-Weberian paradigm as the best option was strongly supported by (Drechsler, 2005a). The question is, which paradigm is best (or most suitable) in a practical sense, to choose for the purposes to overcome the present administrative crisis? My thesis here is also negative: to select the best paradigm from the existing list is impossible. All of the basic administrative paradigms at present fail principally because they can't lead to success toward eliminating the administrative crisis. Moreover, if one pretends to find solutions using only the limited, existing basic administrative paradigms' approaches, it will lead toward the multiplication of the contemporary problems of governance.

Question 4. Finally, as the last variant of the research question, I would like to ask whether it is possible to find a new administrative paradigm, which will be relevant in its administrative mechanisms to a proper reaction to the crisis of contemporary governance. The thesis (hypothesis) of the article is that this is the only way out of the present administrative crisis. Hence, future research should be committed to the discovery of principles and administrative mechanisms for this hypothetical new paradigm.

\section{Review of approaches (literature)}

Discussions on which kind of governance is needed to overcome the current crisis are mainly concentrated around the external context of governance, its public nature. The reasons for paying so much attention to the external context 
of governance are simple: governments first of all are inefficient in their relations with citizens. As G. Peters wrote, «"the most fundamental paradox has been that while along many dimensions public administration has improved much of its internal performance, it is currently regarded publicity as even more inefficient and ineffective than ever" (Peters, 2013, P. 315). In addition, it is a deep conviction of many researchers that to improve governance, one must change the political and cultural context, not the internal administrative mechanisms, which are secondary and dependent of the context. The significance of the external context for the improvement of governance is expressed clearly by V. Junjan and R. Torenvleid (Junjan \& Torenvleid, 2016). They stressed that "Public management reforms (but also public management research on reforms) have put too much emphasis on government control and not enough emphasis on democratic responsiveness. In Central and Eastern European countries (CEECs), these imbalances have led to unsustainable reforms, harming the quality of public service delivery and also political stability" (Ibid, p. 321).

In the case of the EU, a multitude of problems - involving migration, political authoritarianism, Brexit, the concentration of decision-making at the level of the European Commission, and rising indebtedness - have been the most significant issues for governance in recent years ${ }^{1}$. For China, the essentially oneparty (in essence) political system and ideology of communism, which exists to this day, are considered both the foundation of social stability and as the obstacle to administrative reform.

The neo-institutional approach gives a good insight into a better understanding of the external approach toward changes in public administration (Kuhlmann, Wollmann, 2014, P. 44-47). In Russia, several researchers also trace the fundamental problems of governance to neo-institutional peculiarities of a political system. Neopatrimonialism and the cynical behavior of the Russian elite are the main barriers to administrative reform (Gelman, 2015, P. 7). A transitional state crisis related to the indefiniteness of all social processes in the country, which is completely applicable to Russia, is embodied in malfunctions of governance, in tensions within the Russian state institutional design (weak legitimacy of governance, and, as result the orientation of governance not to effectiveness, but to social fairness and to justification; and weak coordination and accountability of bureaucracy (Kupriashin, 2015, P. 5).

However, despite the external approach toward the re-shaping of governance in the prevailing conditions of crisis, the internal approach to overcoming administrative crisis also exists. Its position is that no progress in governance is possible unless appropriate administrative mechanisms are developed. Moreover, small technical steps in providing progress in administrative mechanisms of governance (the so-called, "theory of small deeds") are more fruitful than any institutional transformations. This position clearly contradicts the already cited thesis that the development of administrative mechanisms is secondary in overcoming a governance crisis.

\footnotetext{
This was M. Potucek's recent discussant thesis at the Annual Meeting of the International Network for Social Policy Research and Teaching, Milano, October 23-25, 2016.
} 
Internal (intrinsic) re-shaping of governance connects progress in governance with the possibility of existing administrative paradigms to be functional and deliver results. The internal position is embodied in three different variants that are discussed in the course of administrative reform implementation:

1) The transition from the NPM paradigm ("adieu, consumers' epoch"). The idea is to dismiss NPM tools as outdated at the time of crisis, or to use them together with other tools beyond NPM (Christensen and Lægreid, 2007). A review of this position and related sources, traced by researchers (De Vries, Nemec, 2013) back to 1988, and which have become the "motto" today, is resumed by them in the words about present changes in the usage of NPM administrative mechanisms: "Common paradigm (NPM - A.B.) shifts are also visible in a shift of emphasis from short-term goal achievement to the need to address long-term effectiveness; from a shift in emphasis from efficiency to effectiveness; from outputs to outcomes; from input (what is put in) to the thinking process (how to do it), et cetera" (ibid., p. 8).

2) The transition toward a neo-Weberian paradigm ("vivat, ethical state"). The roots of this position are embedded in understanding that administrative technique without reflexive behavior has become a kitsch which "can be pre-digested, prepackaged, and sold as a largely unproblematic activity with a barely disguised 'how-to' training guide intends" (Samier, 2005, p. 39). Of course, the reflexive position means that we recognize critical thinking and behavior as ethical categories that give soul to the administrative procedure. As Samier wrote "what does it mean to BE an administrator, beyond and underlying the professional duties and technical skills formally prescribed"? (ibid, p. 18). It gives a new birth to the Weberian paradigm as reincarnated into a neo-Weberian ethical shape.

3) The transition toward Good Governance (New Public Governance) paradigm ("welcome, shared governance"). The administrative mechanisms guided by bureaucracy should be replaced by mechanisms whereby decision-making is attributed to the participation of civil society. "This model emphasizes relationships between the population, public servants, and other actors (for example nonprofit organizations), and the organizational landscape is characterized by networks, inter-organizational relationships, and multi-actor policy-making" (cited from: Sicilia, Guarini, Sancino, Andreani, Ruffini, 2016, P. 11). The co-production of public services as voluntary efforts by individuals and groups to enhance the quality of services they use has become the focal point of new public governance (Brandsen, Pestoff, Verschuere, 2012), with the outsourcing of some administrative functions (Obolonsky, Barabashev, 2014). The idea of NPM, that the government should be oriented towards market and business, is replaced by the idea that the population should be a co-producer of a new public value.

\section{Study of the research questions}

To answer the research questions raised in the previous section of the article, I would point out that it is not proof in a strong (G.W. Leibniz) sense. Rather, 
it is a reasonable argumentation in support of my position, because the subject of research lies in the field of the theory of public administration, and all rationale here is also theoretic: it is reasoning, not calculations.

\section{Reasoning on question 1 (to accept all administrative mechanisms from dif- ferent administrative paradigms simultaneously)}

Let us consider higher administrative personnel management. What might the consequences of simultaneous usage of managerial mechanisms produced by different administrative paradigms be? This has already been done in Russia, and the results can be evaluated as a negative experience.

To describe the sets of different mechanisms, the management of higher personnel can be founded on:

(1) A meritocratic approach toward selection and promotions. It is the Weberian paradigm toolkit, based on the evaluation of the level of professional competencies, on resume analysis (professional education and experience), on the testing of professional skills and abilities to solve the problems, and on participation in educational and training programs. Such an approach is most effective in establishing a unified government structure that has the authority to guide the selection and nomination of personnel to positions and the promotion of higher administrative personnel. It should be more or less similar to the functions of the Office of Personnel Management in the USA (Wyen, Beeck, Hondeghem, 2013; Mann, 2009; Lobanov, 2006). As for Russia, we can see some elements of such an approach in the merit-based procedures of recruitment and promotion of personnel reserves. These procedures are established in Russian civil service legislation and currently supported by the ML.

(2) Another approach toward working with higher administrative personnel can be seen in the NPM paradigm that proposes other kinds of administrative tools. Here the accent is on the evaluation of service effectiveness. It consists of mechanisms for evaluating the effectiveness of process (through administrative regulation of services, so-called "administrative reglaments (rules)," and the scrupulous adherence to job descriptions). Citizens, as consumers of public services, are given priority in evaluations. Higher administrative personnel should take full responsibility for the quality of services, and weak indicators should lead to administrative penalties for state managers. The ML of Russia has elaborated some recommendations of methods for governmental bodies on how to evaluate administrative personnel in this way (ML of Russia, evaluation procedures, 2016). The recent transformation of the NPM administrative mechanisms for the performance measurement of higher administrative personnel has led to a new emphasis on the evaluation of strategic activity and the achievement of objectives (Bozhya-Volya, 2009; Rato, Baptista, Ferraz, Rodrigues, 2008). The transformation also has led to the evaluation of flexibility in goals and task setting as well as the achievement of targeted results (Bouckaert, Halligan, 2007). As a consequence, in the context of NPM administrative mechanisms, the relevant administrative bodies should have access to higher administrative personnel, and there is no need for an overall central authority (such as OPM in the USA), because neither professional 
competencies nor continuous educational programs are critical for promotions based on the delivery of specific services or the development of strategy for particular administrative bodies.

(3) The "Open Government" approach, as in the part of New Public Governance administrative mechanisms. This approach involves the willingness of top civil servants to work in close contact with NGOs and citizens, to share decision-making responsibilities, to accept voluntary assistance, to facilitate public decision making and to become the agents who carry out thise decisions (Sicilia, Guarini, Sancino, Andreani, Ruffini, 2016), and to become bearers of a new type of administrative culture of co-production (Alford, 2009). To be "mediagenic", to enjoy public credibility and charisma, to have the capability to listen to people, to change one's position and to lead - these are the remarkable features of higher administrative personnel. Such features either exist "naturally" or are wholly absent. It is possible to improve upon them, or to weaken them through inappropriate actions, but not to create them "from scratch". That is why it is possible for outsiders to enter the "administrative elite." It is also why such procedures as standard educational training and selection by merit (or on the basis of the effectiveness of services delivery) are not sufficient here. Also, such charismatic leaders are quite difficult to fire from their positions because of their visibility and popularity. Any personnel managerial structure or structures are incapable of producing such leaders; instead, they simply appear naturally.

Is it wise to blend all three sets of administrative mechanisms described above in working with higher administrative personnel? In Russia, such an eclectic effort is being attempted right now. Hence, we receive such unpleasant results as:

- The programs of training and continuous education for higher personnel are made merely "for show," formalistically, and their results are not considered to be grounds for promotion;

- Personnel management bodies are not unified, and their responsibilities overlap. (Russia has at least three competing structures: within the ML of Russia, in the Administration of the President of Russia, and in the Apparatus of the Government of Russia.) Likewise, the HR units also exists in each governmental body;

- Higher personnel' responsibilities are unclearly articulated.

This raises a number of crucial questions. How should one work with top administrative personnel? Who should be promoted, and why? Which unit will be responsible for top administrative officials, their selection, training, and promotion? Different paradigms offer answers that are controversial. This shows the failure of the eclectic combination of tools from all of the basic administrative paradigms, at least in Russia and in this particular case. Remarkably, other lines of reasoning all lead to the same conclusion. To support the transition from NPM to neo-Weberian paradigm in Central and Eastern European countries, W. Drechsler writes "Yet, with systems as heterogeneous as NPM and "Weberian" PA, most elements are not functional outside of their context, and might even destroy the mechanics of another system. Too much flexibility in a merit system, for instance, ruins its advantages" (Drechsler, 2005 b, P. 102). 
The results of the analysis can be presented as a diagram (Diagram 1):

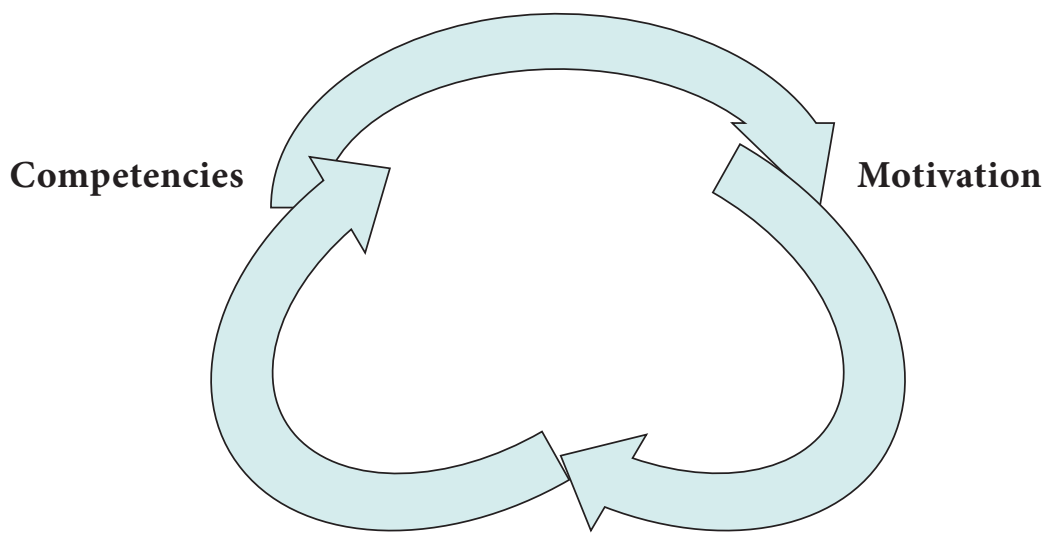

Effectiveness

The diagram expresses the contradictions in administrative mechanisms proposed by the basic administrative paradigms. Actually, the fundamental differences among the three types of selection and promotion suggest that it is impossible to combine them.

\section{Reasoning on question 2 (to cherry pick the best mechanisms from different paradigms)}

To cherry pick the "best" administrative tools and procedures from basic administrative paradigms, we need to compare theoretical and practical disadvantages of the administrative mechanisms. The goal is to reject administrative mechanisms that present significant obstacles to their usage in conditions of administrative crisis. It is better to show these disadvantages in the form of a table (Table1).

Table 1

\section{Disadvantages of administrative mechanisms proposed by basic administrative paradigms}

\begin{tabular}{|c|c|c|c|}
\hline Paradigm & $\begin{array}{l}\text { Basic theoretical } \\
\text { principles }\end{array}$ & $\begin{array}{l}\text { Theoretical } \\
\text { disadvantages }\end{array}$ & Practical disadvantages \\
\hline \multicolumn{4}{|c|}{$\begin{array}{c}\text { Ideal Weberian state / Meritocracy } \\
\text { Neo-Weberian state / Ethical meritocracy }\end{array}$} \\
\hline Structural ideal state & $\begin{array}{l}\text { Formation } \\
\text { of responsible } \\
\text { state as the set } \\
\text { of procedures, } \\
\text { that helps to specify } \\
\text { the structure and } \\
\text { responsibilities } \\
\text { of governmental } \\
\text { bodies }\end{array}$ & $\begin{array}{l}\text { The structure } \\
\text { of governmental } \\
\text { bodies cannot } \\
\text { be fixed permanently, } \\
\text { it is flexible }\end{array}$ & $\begin{array}{l}\text { Structural reforms } \\
\text { of government are not } \\
\text { relevant to the administrative } \\
\text { crisis; they become outdated } \\
\text { too quickly. Moreover, } \\
\text { the structural reforms lead } \\
\text { to temporary disorganization } \\
\text { of governance (for up to } \\
\text { a one-year period, as it was } \\
\text { in Russia in 2004) }\end{array}$ \\
\hline
\end{tabular}




\begin{tabular}{|c|c|c|c|}
\hline Paradigm & $\begin{array}{l}\text { Basic theoretical } \\
\text { principles }\end{array}$ & $\begin{array}{c}\text { Theoretical } \\
\text { disadvantages }\end{array}$ & Practical disadvantages \\
\hline Ethical meritocracy & $\begin{array}{l}\text { Formation } \\
\text { of professional ethics } \\
\text { of civil service - } \\
\text { creation of the } \\
\text { ethical infrastructure } \\
\text { of governance }\end{array}$ & $\begin{array}{l}\text { Professional ethics } \\
\text { is not separate from } \\
\text { general ethics, but } \\
\text { rather is culturally } \\
\text { and socially } \\
\text { dependent upon it }\end{array}$ & $\begin{array}{l}\text { Unimpeachable professional } \\
\text { ethical behavior cannot, } \\
\text { by itself, replace correct } \\
\text { and rapid response } \\
\text { to innovative changes } \\
\text { (phenomena of ethical, } \\
\text { but not effective actions) }\end{array}$ \\
\hline $\begin{array}{l}\text { Motivational } \\
\text { meritocracy }\end{array}$ & $\begin{array}{l}\text { Improving } \\
\text { motivation of civil } \\
\text { servants toward PSM }\end{array}$ & $\begin{array}{l}\text { Public interests } \\
\text { are impossible } \\
\text { to determine without } \\
\text { contradictions }\end{array}$ & $\begin{array}{l}\text { Motivation is oriented toward } \\
\text { a stable system of values. } \\
\text { But due to innovative } \\
\text { processes, the goals and } \\
\text { conditions of governance are } \\
\text { changing, and it is followed } \\
\text { by rapid changes in priorities } \\
\text { and values }\end{array}$ \\
\hline $\begin{array}{l}\text { Competence-based } \\
\text { meritocracy }\end{array}$ & $\begin{array}{l}\text { Improvement } \\
\text { of professional } \\
\text { competencies } \\
\text { of civil servants } \\
\text { and elaboration } \\
\text { of qualification } \\
\text { requirements for job } \\
\text { positions }\end{array}$ & $\begin{array}{l}\text { Professional } \\
\text { competencies are } \\
\text { hard to determine, } \\
\text { and professional } \\
\text { qualifications } \\
\text { requirements are } \\
\text { too generic and } \\
\text { conditional }\end{array}$ & $\begin{array}{l}\text { In an administrative crisis, } \\
\text { all professional competencies } \\
\text { become dynamic and quickly } \\
\text { outdated }\end{array}$ \\
\hline \multicolumn{4}{|c|}{ NPM / effective bureaucracy } \\
\hline State of services & $\begin{array}{l}\text { Regulation of the } \\
\text { functionality } \\
\text { of governmental } \\
\text { bodies and } \\
\text { elaboration } \\
\text { of regulatory } \\
\text { measures for the } \\
\text { delivery of services }\end{array}$ & $\begin{array}{l}\text { Administrative } \\
\text { regulation of the } \\
\text { delivery of services } \\
\text { does not embrace } \\
\text { all functions } \\
\text { of governmental } \\
\text { bodies. It is impossible } \\
\text { for prescriptive } \\
\text { regulations to take } \\
\text { all possibilities and } \\
\text { details into account }\end{array}$ & $\begin{array}{l}\text { The administrative process } \\
\text { of regulation slows decision- } \\
\text { making, whereas a crisis } \\
\text { requires fast and flexible } \\
\text { response mechanisms }\end{array}$ \\
\hline $\begin{array}{l}\text { Regulatory state } \\
\text { oversight and impact } \\
\text { assessment }\end{array}$ & $\begin{array}{l}\text { Elaboration of the } \\
\text { procedures that can } \\
\text { improve effective } \\
\text { oversight, such } \\
\text { as inspections, } \\
\text { checklists, and } \\
\text { so on, and prevent } \\
\text { unjustified } \\
\text { regulation }\end{array}$ & $\begin{array}{l}\text { Oversight functions } \\
\text { are growing } \\
\text { as metastases, } \\
\text { entailing further } \\
\text { risks of corruption. } \\
\text { In addition, oversight } \\
\text { measures are largely } \\
\text { incomplete }\end{array}$ & $\begin{array}{l}\text { Transaction costs } \\
\text { of oversight increase } \\
\text { in crisis conditions, because } \\
\text { the oversight procedures } \\
\text { are too inflexible }\end{array}$ \\
\hline $\begin{array}{l}\text { Processes: Effective } \\
\text { bureaucracy } \\
\text { (KPI and BSC } \\
\text { effectiveness of civil } \\
\text { servants) }\end{array}$ & $\begin{array}{l}\text { Elaboration and } \\
\text { improvement of the } \\
\text { tools for evaluating } \\
\text { the actions of civil } \\
\text { servants }\end{array}$ & $\begin{array}{l}\text { The evaluation } \\
\text { of outcomes } \\
\text { is replaced by that } \\
\text { of outputs and } \\
\text { the effectiveness } \\
\text { of processes; this } \\
\text { makes it hard } \\
\text { to identify which } \\
\text { professional activity } \\
\text { is successful }\end{array}$ & $\begin{array}{l}\text { To work not for real } \\
\text { effects, but for "indicators", } \\
\text { is dangerous. Also, the } \\
\text { introduction of indicators } \\
\text { has a chilling effect on the } \\
\text { initiative of civil servants }\end{array}$ \\
\hline
\end{tabular}




\begin{tabular}{|c|c|c|c|}
\hline Paradigm & $\begin{array}{l}\text { Basic theoretical } \\
\text { principles }\end{array}$ & $\begin{array}{l}\text { Theoretical } \\
\text { disadvantages }\end{array}$ & Practical disadvantages \\
\hline $\begin{array}{l}\text { Strategic and } \\
\text { planning effectiveness } \\
\text { of bureaucracy }\end{array}$ & $\begin{array}{l}\text { Elaboration of the } \\
\text { instruments } \\
\text { for evaluation } \\
\text { of strategic } \\
\text { effectiveness, } \\
\text { including SMART } \\
\text { and PEST analysis. } \\
\text { Elaboration of the } \\
\text { instruments for } \\
\text { evaluation of the } \\
\text { plans of professional } \\
\text { activity }\end{array}$ & $\begin{array}{l}\text { Strategic effectiveness } \\
\text { cannot possibly } \\
\text { be introduced, } \\
\text { because the strategy } \\
\text { is just an optional } \\
\text { selection of goals. } \\
\text { Also, strategic } \\
\text { effectiveness is not } \\
\text { attributed to "line" } \\
\text { servants, but just } \\
\text { to managerial level } \\
\text { servants. Executive } \\
\text { staff should not } \\
\text { discover their own } \\
\text { strategies. } \\
\text { The plans are } \\
\text { constructed from } \\
\text { existing conditions } \\
\text { and are provisional }\end{array}$ & $\begin{array}{l}\text { Strategic effectiveness of civil } \\
\text { servants' activity at the time } \\
\text { of administrative crisis is not } \\
\text { sustainable: the conditions } \\
\text { and goals of governance } \\
\text { change rapidly. Planning } \\
\text { becomes problematic } \\
\text { due to the emergence } \\
\text { of unpredictable new } \\
\text { settings }\end{array}$ \\
\hline \multicolumn{4}{|c|}{$\begin{array}{l}\text { New Public Governance State / } \\
\text { bureaucracy of participation }\end{array}$} \\
\hline $\begin{array}{l}\text { Participatory } \\
\text { governance }\end{array}$ & $\begin{array}{l}\text { Elaboration and } \\
\text { decision-making } \\
\text { in interaction } \\
\text { with civil society } \\
\text { (governance } \\
\text { as the network } \\
\text { of communications } \\
\text { with civil society } \\
\text { organizations and } \\
\text { citizens) }\end{array}$ & $\begin{array}{l}\text { It is difficult } \\
\text { to formalize } \\
\text { the network } \\
\text { of communication } \\
\text { and clearly determine } \\
\text { the conditions } \\
\text { and boundaries } \\
\text { of collective decision- } \\
\text { making }\end{array}$ & $\begin{array}{l}\text { In practice, lobbying } \\
\text { by private and certain } \\
\text { peculiar social groups } \\
\text { is not excluded. How are } \\
\text { the "pseudo-structures" } \\
\text { eliminated when they are } \\
\text { created just for material } \\
\text { profits (distribution } \\
\text { of public funds)? } \\
\text { It is especially significant } \\
\text { in time of crisis, when } \\
\text { the tensions between } \\
\text { different group interests } \\
\text { increase }\end{array}$ \\
\hline $\begin{array}{l}\text { State of stratified } \\
\text { participation } \\
\text { of different social } \\
\text { actors, and of co- } \\
\text { production }\end{array}$ & $\begin{array}{l}\text { Elaboration } \\
\text { of decisions } \\
\text { in interaction with } \\
\text { different social } \\
\text { actors (business, } \\
\text { state-established } \\
\text { organizations, } \\
\text { NGOs, citizens) }\end{array}$ & $\begin{array}{l}\text { Conditions } \\
\text { and boundaries } \\
\text { of collective decision- } \\
\text { making processes are } \\
\text { overly complicated }\end{array}$ & $\begin{array}{l}\text { Manipulation from the state, } \\
\text { especially in transitional } \\
\text { and developing countries, } \\
\text { increases if the social } \\
\text { contract does not exist. } \\
\text { Also, the set of actors } \\
\text { at the time of crisis } \\
\text { is constantly changing }\end{array}$ \\
\hline State of outsourcing & $\begin{array}{l}\text { The transfer } \\
\text { of governmental } \\
\text { responsibilities and } \\
\text { functions to external } \\
\text { organizations (NGOs, } \\
\text { businesses, etc.) }\end{array}$ & $\begin{array}{l}\text { It is difficult to discern } \\
\text { the criteria by which } \\
\text { responsibilities should } \\
\text { be transferred. Also, } \\
\text { the governmental } \\
\text { responsibilities } \\
\text { and people's rights } \\
\text { to participate } \\
\text { contradict each other } \\
\text { frequently }\end{array}$ & $\begin{array}{l}\text { Potential corruption } \\
\text { in the transfer of state } \\
\text { responsibilities to other } \\
\text { entities }\end{array}$ \\
\hline
\end{tabular}




\begin{tabular}{|l|l|l|l|}
\hline \multicolumn{1}{|c|}{ Paradigm } & \multicolumn{1}{|c|}{$\begin{array}{c}\text { Basic theoretical } \\
\text { principles }\end{array}$} & $\begin{array}{c}\text { Theoretical } \\
\text { disadvantages }\end{array}$ & \multicolumn{1}{c|}{ Practical disadvantages } \\
\hline $\begin{array}{l}\text { Co-productive } \\
\text { bureaucracy (sharing } \\
\text { responsibilities } \\
\text { for decision- } \\
\text { making, accepting } \\
\text { voluntarism } \\
\text { by individuals } \\
\text { and groups) }\end{array}$ & $\begin{array}{l}\text { Network distribution } \\
\text { of the responsibilities } \\
\text { and duties }\end{array}$ & $\begin{array}{l}\text { Unclear how } \\
\text { to formulate shared } \\
\text { responsibility } \\
\text { for decisions }\end{array}$ & $\begin{array}{l}\text { Administrative crisis } \\
\text { sharpens social } \\
\text { contradictions, making } \\
\text { it hard to achieve consensus } \\
\text { in decision-making }\end{array}$ \\
\hline
\end{tabular}

It is clear from this list that practical and theoretical disadvantages are closely connected. To generalize, an administrative crisis, which is itself an aspect of the global crisis of governance brought on by imbalances produced by innovative development, sheds light on the weak aspects of existing administrative mechanisms. It is impossible to avoid certain theoretical disadvantages and to take only the "best" practical instruments: for every theoretical justification there is a corresponding disadvantage, like two sides of a coin. In other words, it is no more possible to take only some of the practically "best" tools and to dismiss their theoretical derivation of the theory, any more than it is possible to cut off one side of a coin and just use the other side.

The deep reason for such a conclusion is found in recognizing that every administrative mechanism has its organizational structure of implementation, period of activation, and consequences of exploring. Notwithstanding the attempt to draw only from the "best" (practical) mechanisms of different theoretical origins, each such mechanism requires different organizational support, and they will be not compatible in times of action.

For example, many problems arise in the attempt to understand the civil service as an object (an essence) according to Weberian and neo-Weberian paradigms, and to apply standard merit-based procedures to selecting, promoting and motivating civil servants. These problems include the following: to struggle with the instability of professional competencies; to apply moral values to innovative social relations; and to introduce initiative into the traditionally legalistic behavior of civil servants in the dynamic World. Let's try to improve, for instance, on the Weberian tools by borrowing other "best" administrative mechanisms from NPM and NPG. Usually, attempts to improve the civil service include such measures as effectiveness-oriented remuneration (bonuses, or other incentives) based on the results of the delivery of services, increasing the transparency of professional activity of civil servants (placing more information on websites, introducing feedback mechanisms for consumers of services, etc.), and anticorruption measures (reports, whistleblowing, etc.). Unfortunately, to blend all those administrative tools together and use them simultaneously would create tensions in the systems of contemporary civil service:

- For any ministry of finance, calculating funding limits for government personnel is much easier bonuses are not taken into account. With everything changing rapidly, it is well nigh impossible to declare the total amount of funds needed for bonuses for any specific governmental body's 
personnel. In the present crisis, with instability and shifting priorities, it looks like it is the spontaneous and contextual made decisions that express the ranking of governmental bodies in the eyes of political authorities. Additionally, bonuses are given with a delay, not when they are earned. Finally, bonuses have a tendency to become part expected as an entitlement (part of regular salary).

- Introducing transparency in civil servants' professional activity heavily influences the relationships among civil servants themselves. From an organizational standpoint, the system of orders from managers to the executive staff will be under pressure: all of the orders can be discussed openly and evaluated negatively by the public. The unpredictability of such "approval leaks" is obvious. As a result, the hierarchical Weberian organizational system of a civil service (principal theoretical construction for Weber and neoWeber paradigm) will be damaged.

To conclude, the state and its bureaucracy cannot be determined by some blended system of administrative tools and procedures, borrowed from among the best elements of different administrative paradigms, because of organizational and other reasons that reflect the unstable environment of present governance.

\section{Reasoning on question 3 (to take only those mechanisms that belong exclu- sively to one basic administrative paradigm)}

I would like to divide the analysis of this approach into two parts.

The first concerns historical progress in paradigms. According to accepted wisdom, every country's administrative development should pass in stages from the Weberian state to a service-oriented state, and only after that to the state-oriented new public governance. This belief is based on the assumption that it is not possible to expunge in one sweep the relics of previous systems of state management, on the one hand, while, on the other, a smooth transition is necessary according to general globalist unification of governance systems. Theoretically, this belief is traced to institutionalism and to the theory of public choice (Norgaard, Winding, 2006, P. 138, 147). However, every administrative paradigm has a set of its own theoretical deficits and interwoven practical disadvantages (as shown before), which has become more and more inappropriate at the time of administrative crisis. Therefore, the transition from one set of administrative paradigm mechanisms to another - the "next" paradigm in line is no progress at all. One kind of defect is simply replaced by another, and the problems, far from being solved, are replaced (or rather multiplied) by still others. The quality of governance is not necessarily enhanced: it looks more like "chasing after some theoretical fashion" and the desire to conform with other countries that have already applied the next generation of models and theories of state and bureaucracy. Such a chase can be destructive for the country, because the unthinking adoption of new models and social theories is potentially dangerous for the existing social reality inside a country.

Every existing basic administrative paradigm is ill-fitted to overcome the contemporary administrative crisis. Actually, from NPM's perspective on the state and its functions, the complete regulation of services is theoretically im- 
possible. More significantly, imposing stringent regulations everywhere stifles flexibility in decision-making. Moreover, the indicators of service effectiveness fail to take into account the indefiniteness of innovation: they replace outcomes with outputs and "measurement of processes" and cultivate the preparation of unwieldy and time-consuming formal plans of professional activity. Speaking of services, the present administrative crisis is not mainly connected with low quality public services. It stems from the rapid, revolutionary changes of social life. As a result, high quality but outdated public services can be harmful. Just a few examples: social programs of support for workers in an ecologically harmful line of work help to sustain an industry that is outdated; for many services, it is better simply to stop them rather than to try to improve them. Also, the maxim "the consumer is always right" is not correct in times of innovation, because a lot of innovations are potentially harmful to the environment. To appease consumers in all their desires means to intensify the crisis of governance, which is already incapable of limiting rampant consumption and the exacerbation of social tensions.

It is the same with the paradigm of New Public Governance administrative mechanisms. Such mechanisms are flawed because, at the present time of misbalanced innovative development and administrative crisis, it is not possible to delimit the boundaries of participation. Contradictions among participants broaden, and their interests diverge. The risks to follow lobbying interest of some social groups increase, and social consensus start to be imitated rather than achieved.

Unfortunately, the idea of historical progress in administrative paradigms leads to a negative conclusion. The necessity of moving from instruments of a previous paradigm to the those of another because of their "better suitability" for contemporary administrative practice is not evident.

Now I will explore the second, "softer" optional variant of the "best paradigm" selection. Instead of historic progress in the use of administrative paradigms in the practice of governance, let's suppose that the "right governance" looks different for different countries (Andrews, 2010). The existence of specific social, economic, and cultural conditions and traditions of regional peculiarities produce a certain predisposition of the country and its system of governance toward some particular administrative paradigm.

Suppose one can choose the particular administrative mechanisms of a paradigm that is capable of overcoming an administrative crisis. For example, for those countries with a high level of governance culture, strong ethical norms in their civil service "community," and a developed civil society, the New Public Governance paradigm can be the best choice to orient to. However, technical and social innovations can destroy the balance of interests of social groups and create a crisis of public participation in governance.

For countries with a strong system of bureaucracy and a tradition of supremacy of bureaucracy in social life (that is, imperial tradition), without the mature institutions of civil society, the transition toward New Public Governance would only wreak havoc with governance institutions. At the time of turmoil it could lead to the destruction of administrative mechanisms (including a pause in decision-making procedures). In this case it is better to orient to the Webe- 
rian paradigm and its contemporary models. In particular, societies in a position of post-Soviet transition tend to favor the models of ethical meritocracy and public service motivation (and if their elites are not reformed, these models tend to disappear). A characteristic feature of the usage of these models is the training of new professional skills through the formation of ethical standards and strengthening control and supervision to combat corruption. The distinguishing feature of these countries is the widespread belief that the administrative measures of meritocratic orientation will lead to a new quality of public administration: it will help to overcome the incompetence of civil servants and contribute to a new tradition of professional ethics and motivation towards public service. However, this aspiration is like chasing a ghost: innovative development devalues existing professional competencies, which become outdated. At the same time, ethical standards and motivational preferences are subject to the destructive influence of innovation and lifestyle changes. They are rapidly evolving over the course of reforms (Belle, Ongaro, 2014).

The countries in which there is significant public distrust of government institutions, and of how they perform, tend to favor the formation of NMP-state oriented services. They pretend to regulate performance processes and to assess the effectiveness of civil servants on the basis of performance. But the regulation of public service functions and process-oriented evaluations of performance are useless and even counter-productive if public services and performances are rapidly changing, if new products are formed constantly.

To conclude, selection of the "best paradigm" from already existed, as suitable for overcoming the administrative crisis is not possible. The "optimal solution" does not exist: all three basic administrative paradigms can mitigate the effects of an administrative crisis to a greater or lesser extent, depending on the conditions (country, region, cultural features, administrative traditions, etc.), but they are not capable of offering the tools to completely eliminate the crisis. This is clearly evident for African countries (Andrews, 2012). The administrative paradigms can provide the tools to struggle with an administrative crisis triggered by contemporary imbalances of innovative development, but cannot create the tools to overcome the crisis.

The main defect of the existing administrative paradigms is that they are always «one step behind the crisis;» i.e., they offer a design and procedures to respond to the crisis, but only with a delay. They are based on fundamental principles that differ from those of the crisis, its causes and its main parameters. Existing administrative paradigms come from other epochs and rest on theoretical principles suitable for periods of stable development, with their predictability and certainty. The contemporary crisis, in contrast, appears to these paradigms as the "outside call,", as something alien. From existing paradigms' prospects, the crisis is an extraordinary and temporary circumstances that make governance more complicated for just a limited period of time, which, it is hoped, will end soon.

I argue that administrative theory of governance at present is not able to meet the challenges of innovative development. The existing administrative paradigms are inadequate to overcome the current crisis of governance. 


\section{Reasoning on question 4 (to find a new administrative paradigm): In lieu of a conclusion and of discussion}

In a quest for a new administrative paradigm, we need to ask the questions: "What principles are appropriate for this paradigm? Do the beginnings of a new approach exist?" I believe it is possible to point to some research that is going beyond the limits of the existing administrative paradigms, though it has much in common with it.

The main principles of a new hypothetical administrative paradigm should reflect the elements of the crisis so that it can translate them into the language of positive actions. Such actions should arrest the development of crisis phenomena at their very onset.

First of all, we need to agree that the role of the state at present has changed radically due to challenges of innovative development. The state used to be recognized as a supreme entity, which establishes the rules of fair game in social life. It had been widely held that governance improvement consisted of the enhancement of the rules by the government itself. The imbalances of innovative development and the administrative crisis for their part impose other requirements on the state: we need to evaluate the state in its capacity as a referee; i.e., we must set the rules for a fair evaluation of the referee and thereby to learn how effectively government is handling the crisis and how well it works.

However, such a strong "recipe," despite its universal applicability to all states, can be dangerous, because its use will inevitably reveal the complete ineffectiveness of the government systems of some countries at a time of crisis. Such countries will be forced to acknowledge their administrative impotence. So the fundamental changes in the political and administrative elite, in patterns of social behavior and the national economy, should be introduced. The whole system of governance should be replaced. It is not easy to accept such a cure, perhaps nearly impossible. But it is unclear which choice is better. One choice will mean to avoid the elaboration and application of a fair, objective evaluation of the government; to lag behind; to head towards economic and social degradation; and to rely on surviving crisis conditions and obtaining social cohesion and patience despite the hardships). The other choice will mean to start "to swallow the medicine," to waive traditional governance schemes, and to move away from the sustainable existence of the elites. 


\section{REFERENCES}

1. Alford, J. (2009). Engaging public service clients: From service-delivery to co-production. Basingstoke: Palgrave Macmillan.

2. Andrews, M. (2012). The Logical Limits of Best Practice Administrative Solutions in Developing Countries. Public Administration and Development, vol. 32, no 2, pp. 137-154.

3. Andrews, M. (2010). Good Government Means Different Things in Different Countries. Governance, vol. 23, no 1, pp. 7-35.

4. Barabashev, A. (2016). Krizis gosudarstvennogo upravleniya i ego vliyanie na osnovnye administrativnye paradigmy gosudarstva i biurokratii [Crisis of State Governance and its Influence on Basic Administrative Paradigms of State and Bureaucracy]. Public Administration Issues, no 3, pp. 163-194.

5. Belle, N. \& Ongaro, E. (2014). NPM, Administrative Reforms and Public Service Motivation: Improving the Dialogue between Research Agendas. International Review of Administrative Sciences, vol. 80, no 2, pp. 382-400.

6. Bingham, L., Nabatchi, T. \& O’Leary, R. (2005). The New Governance: Practices and Processes for Stakeholder and Citizen Participation in the Work of Government. Public Administration Review, vol. 65, no 5, pp. 547-558.

7. Bouckaert, G. \& Halligan, J. (2007). Managing Performance: International Comparisons. New York: Routledge.

8. Bozhya-Volya, A. (2009). Otsenka rezultativnosty gosudarstvennykh slyzhaschikh rukovodyaschego sostava: mezhdunarodnyj opyt i rossiyskiye perspektivy [Managerial Civil Servants Performance Evaluation: International Experience and Russian Perspectives]. Public Administration Issues, no 2, pp. 84-103.

9. Brandsen, T., Pestoff, V. \& Verschuere, B. (2012). Co-production as a maturing concept. In: Brandsen,T., Pestoff, V., Verschuere, B. (Eds). New Public Governance, the Third Sector, and Co-production. New York and London: Routledge, pp. 1-9.

10. Brown, G. (2011). Bringing the State Back into Cosmopolitanism: The Idea of Responsible Cosmopolitan States. Political Studies Review, vol. 9, no 1, pp. 53-66.

11. Bryson, J. (2004). Strategic Planning for Public and Nonprofit Organizations. San Francisco, CA: Jossey-Bass.

12. Christensen, T. \& Lægreid, P. (2007). Transcending New Public Management: The Transformation of Public Sector Reforms. New York, NY: Aldershot.

13. De Vries, M. \& Nemec, J. (2013). Public Sector Reform: An Overview of Recent Literature and Research on NPM and Alternative Paths. The International Journal of Public Sector Management, vol. 26, no 1, pp. 4-16.

14. Drechsler, W. (2005a). The Rise and Demise of the New Public Management. Postautistic Economics Review, vol. 14, no 33, pp. 7-28. 
15. Drechsler, W. (2005b). The Re-Emergence of "Weberian" Public Administration after the Fall of New Public Management: The Central and Eastern European Perspective. Halduskultuur, pp. 94-108.

16. Edwards, L. (2012). Strategic Planning in Local Government: Is the Promise of Performance a Reality? Available: http://scholarworks.gsu.edu/cgi/viewcontent.cgi?article= 1037\&context=pmap_diss (accessed: October 28, 2016).

17. Gelman, V. (2015). Modernizatsiya, instituty, and "porochnyj krug" postsovetskogo neopatrimonialisma [Modernization, Institutes, and "Vicious Circle" of Post-Soviet Neopatrimonialism]. St. Petersburg: European University Publ. House.

18. Hințea, C., Profiroiu, M. \& Ticlău, T. (2015). Strategic Planning And Public Management Reform: The Case of Romania. Transylvanian Review of Administrative Sciences, Special Issue (electronic edition), pp. 30-44.

19. Jensen, C. \& Seeberg, H. (2015). The Power of Talk and the Welfare State: Evidence from 23 Countries on an Asymmetric Opposition-Government Response Mechanism. Socio-Economic Review, vol. 13, no 2, pp. 215-233.

20. Junjan, V. (2016). PAR in Academic and Professional Literature: A Comparison of the Recent EU Accession Waves, p. 51-59. Europeization in Public Administration Reforms. Ed. By J. Nemec. Bratislava: NISPAcee Press.

21. Junjan, V. \& Torenvleid, R. (2016). - Roundtable: Is Public Management Neglecting the State? // Governance: An International Journal of Policy, Administration, and Institutions, vol. 29, no. 3, pp. 311-334. doi:10.1111/gove.12201

22. Kuhlmann, S. \& Wollmann, H. (2014). Introduction to Comparative Public Administration. Administrative System and Reforms in Europe. Edward Elgar Publ.

23. Kupriashin, G. (2015). Krizisy gosudarstvennogo upravleniya: neoinstitutsionalnyj podhod [The Crisis of State Governance: Neo-Institutional Approach]. Gosudarstvennoye upravleniye. Elektronnyj vestnik (Elertronnyj zhurnal), no 51, pp. 56-84. Availavle: http://e-journal.spa.msu.ru/vestnik/vipusk/51_2015.htm (accessed: October 28,2016$)$.

24. Lobanov, V. (2006). Rabota s vyshim administrativnym personalom v SSHA i drugikh zarubezhnykh stranah [Work with High Administrative Personnel in the USA and in Other Countries]. Moscow: RAGS Publ. (in Russian).

25. Mann, S. (2009). Beyond a Government of Strangers: How Career Executives and Political Appointees Can Turn Conflict to Cooperation. Review of Public Personnel Administration, vol. 29, no 2, pp. 197-199.

26. ML Of Russia, Competitions (2016). Available: http://www.rosmintrud.ru/ministry/ programms/gossluzhba/17 (in Russian), (accessed: October 28, 2016).

27. ML of Russia, Best Practices (2016). Available: http://www.rosmintrud.ru/ministry/ programms/gossluzhba/14 (in Russian), (accessed: October 28, 2016).

28. ML of Russia, Evaluation Procedures (2016). Available: http://www.rosmintrud.ru/ ministry/programms/gossluzhba/16/4/2 (accessed: October 28, 2016). 
29. Norgaard, O. \& Winding, S. (2006). The Impact of Administrative Traditions on Public Administration Reform: The Baltic Case. Politico-administrative Dilemma: Traditional Problems and New Solutions. Ed. by G. Peters, G. Sootla, B. Connaughton. NISPAcee Press, pp. 137-163.

30. Obolonsky, A. \& Barabashev, A. (2014). How to Clean Out the Augean Stable of Our Bureaucracy. Two Views. Russian Politics and Law, vol. 52, no 2, pp. 77-94.

31. Peters, G. (2013). Dilemmas and Contradictions in the Future of Public Administration. In: The Past, Present, and the Future of Public Administration in Central and Eastern Europe. Bratislava: NISPAcee Press, pp. 315-321.

32. Peters G., Pierre J. \& Randma-Liiv T. (2011). Global Financial Crisis, Public Administration and Governance: Do New Problems Require New Solutions? Public Administration Review, March. DOI: 10.1007/s11115-010-0148-x (date of request December 8, 2016).

33. Pollitt, C. \& Bouckaert, G. (2011). Public Management Reform. A Comparative Analysis. Oxford: Oxford University Press.

34. Rato, H., Baptista, C., Ferraz, D. \& Rodrigues, M. (2008). MANFOR GUIDE. Training Needs Assessment.

35. Samier, E. (2005). Toward Public Administration as a Humanities Discipline. A Humanistic Manifesto. Halduskultuur, pp. 6-59.

36. Sicilia, M., Guarini, E., Sancino, A., Andreani, M. \& Ruffini, R. (2016). Public Services Management and Co-Production in Multi-Level Governance Settings. International Review of Administrative Sciences, vol. 82, no 1, pp. 9-27.

37. Wyen, J., Beeck, S. \& Hondeghem, A. (2013). Interorganizational Mobility within the U.S. Federal Government: Examining the Effect of Individual and Organizational Factors. Public Administration Review, vol. 73, no 6, pp. 869-881. 